\title{
Acute aortic dissection overlapping with herniated discs in thoracic and lumbosacral spine
}

\author{
Rada Vučić ${ }^{1,2}$, Stefan Simović ${ }^{2}$, Mladen Kočica ${ }^{3}$, Vladimir Miloradovićc ${ }^{1,2}$, Ivan Simić ${ }^{1,2}$, \\ Olivera Andrejić ${ }^{4}$ \\ 1,2Department for Internal Medicine, School of Medicine, University of Kragujevac, ${ }^{2}$ Cardiology Clinic, Clinical \\ Center Kragujevac, Serbia, ${ }^{3}$ Clinic for Cardiac Surgery, Clinical Center Belgrade, Serbia, ${ }^{4}$ Clinic for Pulmonary \\ Diseases, Clinical Center Kragujevac, Serbia
}

Abstract

In this study we presented a patient with a chest pain, pain in thoracic and lumbosacral spine, which we supposed that they are consequence of earlier diagnosed herniated disc in thoracic and lumbosacral spine, but they masked clinical picture of aortic dissection. Pain lasted a few days, but patient had dizziness too. At admission day, patient had unconsciousness 1 minute. At first, we suspected on exacerbation of arthritis in thoracic and lumbosacral spine and possible acute coronary syndrome. Exacerbation of herniated discs in lumbosacral spine was confirmed, acute coronary syndrome was excluded, and further evaluation confirmed diagnosis of aortic dissection De Backey type 1 with pericardial hematoma which was treated by surgery.

Key words chest pain, herniated disc, aortic dissection

\section{Introduction}

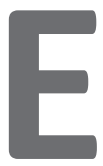
mergency Department is the the most challenging place for reliable and efficient evaluation in identifying patients with life threatening conditions. Initial triage consists of identifying patients with low risk, who can be safely discharged immediately. Unfortunately, clinical presentation, traditional risk factors, clinical risk scores or diagnostic tests allow for a safe initial triage. ${ }^{1}$ On the other hand, organizations of EDs are different between countries, hospitals and doctors. Patients may be seen by cardiologists, ED specialists, internists, neurologists, surgeons. Diseases of heart, aorta, lung, esophagus, stomach, mediastinum, pleura and abdominal viscera may all cause chest discomfort ${ }^{(2)}$. Chest pain is the second common complaint in Emergency Department in United States ${ }^{(3)}$. Differential diagnosis of chest pain is dependent of clinical presentation, ECG, available diagnostic tests, but sometimes life threatening conditions can be unrecognized.

Our patient had two diseases, presenting with mild chest pain and sharp pain in thoracal and lumbosacral spine because of herniated disc Th12/L1 and L5/S1 and life threatening condition - aortic dissection.

Case report description: Patient, 61 years old, was admitted to ED because of unconsciousness for $1 \mathrm{mi}-$ nute at admission day. In a previous medical history, he had arthritis in the thoracic and lumbosacral spine, with herniated discs Th12/L1 and L5/S1. From time to time, he had slow-onset pain between shoulder blades, in lower back, a joint between the spine and the pelvis.
But, sometimes there was a sharp pain in this areas, and the patient couldn't stand up for a weeks. At first, he was taking nonsteroidal anti-inflamatory drugs (NSAIDs) and corticosteroids, but pain didn't relieve significantly. Instead of them, often, he used opioid analgesic - Tramadol hydrochloride, and sometimes for the sharp pain he was using combination of Tramadol hydrochloride and Acetaminophen. Also, he had arterial hypertension, controlled by antihypertensive therapy (Bisoprolol, Ramipril). 7 days before admission, during physical work, patient had mild chest pain, and a sharp pain in back between shoulder blades, both arms, and the pelvis with a exhaustion, swelter and weakness especially of the legs. He couldn't stand up, and he took Tramadol hydrochloride, as he usually did. Pain decreased in intensity, but he had dizziness. During the following days he was taking Tramadol two times'a day, pain intensity and weakness decreased, but were still present.

Physical examination: patient was pale, with rhythmic heart beats, symmetrical, thready pulses of radial and femoral arteries, normal breathing sounds, stomach was without peritoneal reaction. ECG: sinus rhythm, 70 beats per minute, incomplete right bundle branch block (Fig 1). Oxygen saturation was $99 \%$. Blood pressure on right arm was $80 / 50 \mathrm{mmHg}$. At first, possible differential diagnosis were: overlapping exacerbation of herniated discs in thoracic and lumbosacral spine and suspected acute coronary syndrome. Neurological examination showed positive Lazarevic sign (straight - leg - raising), tenderness over the sciatic notch, and confirmed acute lumbosacral herniated disc. Cardiospecific enzymes (CKMB 19 U/L 


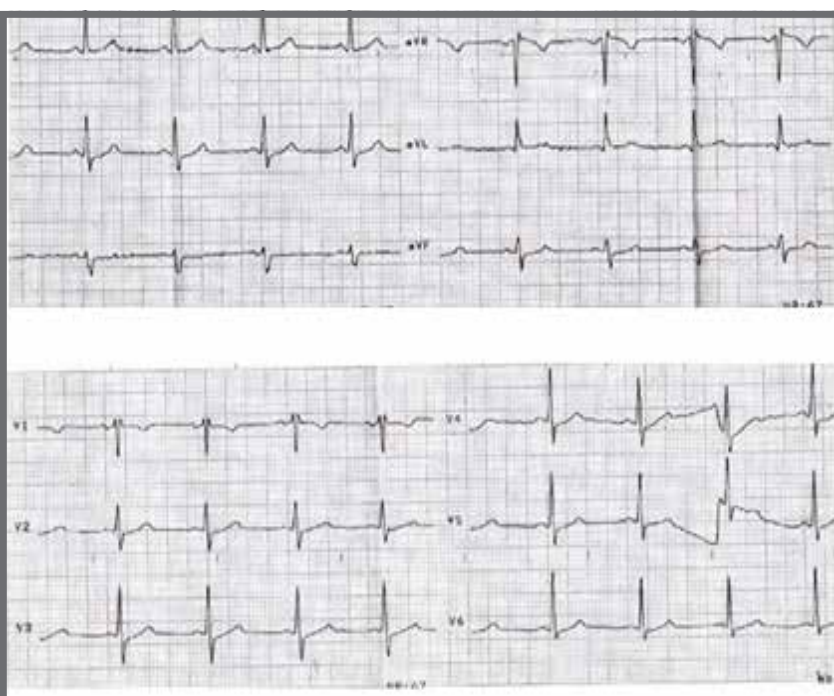

Figure 1. Electrocardiography: sinus rhythm, incomplete right bundle branch block
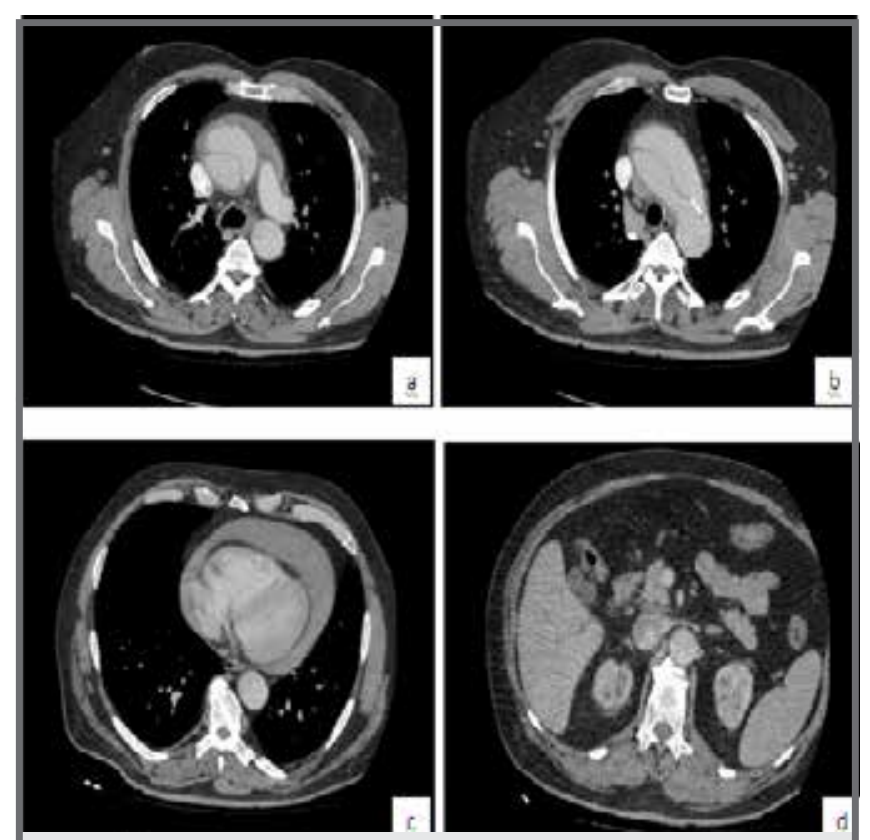

Figure 3. Aortic dissection - MDCT: ascending aorta ${ }^{a}$, $\mathrm{arch}^{\mathrm{b}}$, descending aorta and pericardial effusion with pericardial hematomac, abdominal aorta ${ }^{d}$

(normal range $<25 \mathrm{U} / \mathrm{L}$ ), troponin 0.027 (normal range $<0.04 \mathrm{ng} / \mathrm{ml}$ )) were negative (twice).

Chest radiography showed mediastinal widening, indicating possible acute aortic syndrome. Difference in the blood pressure between the arms wasn't greater than $20 \mathrm{mmHg}$. Laboratory: D dimer was high 5.4 (normal range $<0.5 \mathrm{ug} / \mathrm{ml} \mathrm{FEU}$ ), leukocytes $12 \times 10^{9}$ (normal range 3.7-10 $\times 10^{9}$ ), low hematocrit 0.3 (normal range $0.415-0.53 \times 10^{12}$ ), low haemoglobin $106 \mathrm{~g} / \mathrm{L}$ (normal range $138-175 \mathrm{~g} / \mathrm{L}$ ), high platelet counts $600 \times 10^{9}$ (normal range $135-450 \times 10^{9}$ ), urea nitrogen $19.0 \mathrm{mmol} / \mathrm{L}$ (normal range 3-8 $\mathrm{mmol} / \mathrm{L}$ ) and creatinine $120 \mathrm{umol} / \mathrm{L}$ (normal range 49-106 umol/L). Echocardiography showed acute aortic dissection presenting with pericardial effusion (with pericardial hematoma), dilated ascending aorta with intimal flap in ascendant and abdominal aorta (Fig 2). Multi - detector computed tomography confirmed
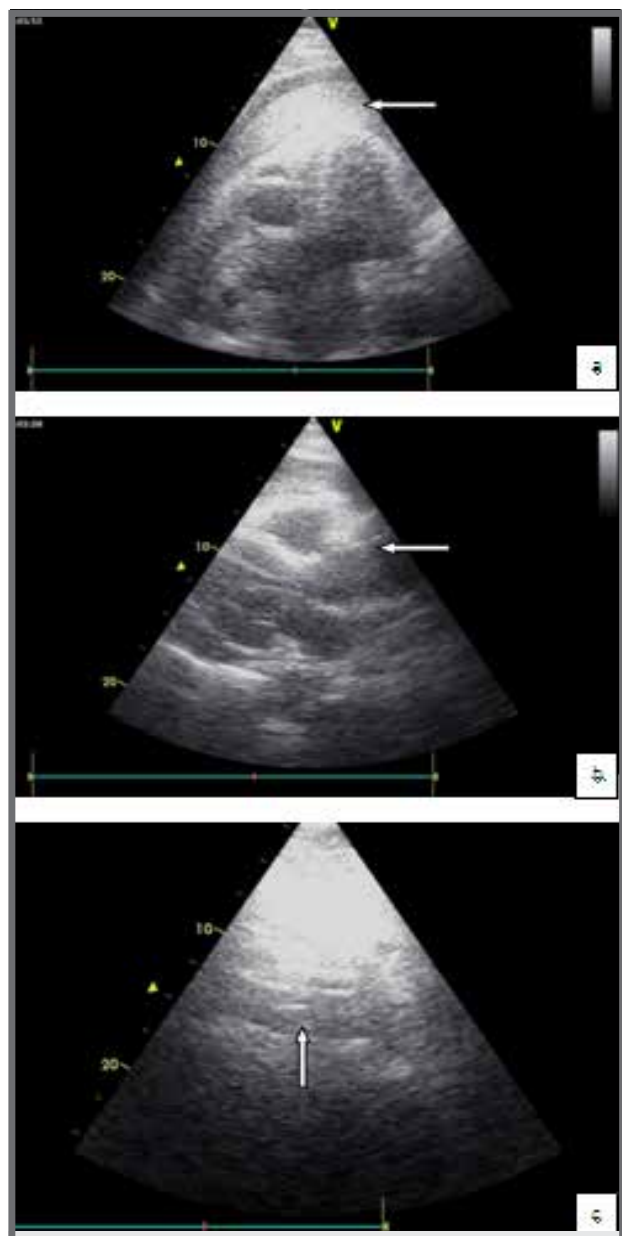

Figure 2. Echocardiography: pericardial effusion with pericardial hematoma ${ }^{a, b}$, dilated ascending aorta with intimal flap in ascending ${ }^{b}$ and in abdominal aortac

aortic dissection type I (from ascending aorta, through thoracic and abdominal segment) (Fig 3). Patient was sent to Cardiosurgery Department in Clinical Centre Serbia, immediately after confirmed diagnosis, where he was operated at the same night (resection of ascending aorta with interposition Dacron graft). One month later, pericardial effusion was still present with fibrous components (Fig 4), and after two months, patient didn't have pericardial effusion (Fig 5). Now, patient is alive, he comes for cardiology control every six months.

\section{Discussion}

Our case report shows patient with arthritis and herniated discs in thoracic and lumbosacral spine, interfering with life-threatening condition, aortic dissection. Diagnosis of arthritis was confirmed a few years earlier, and now neurology confirmed exacerbation of disease. Other symptoms, weakness, especially in legs, dizziness and hypotension could be explained as a consequence of Tramadol use, but patient had unconsciousness for 1 minute at admission day, which requested further evaluation for concomitant diseases. Neurological examination excluded other neurological diseases. According to previously reported studies, con- 


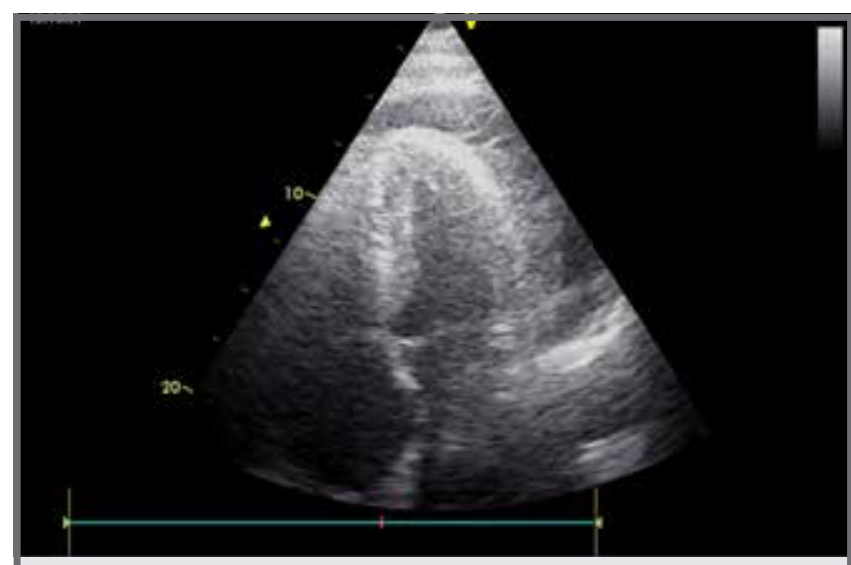

Figure 4. Echocardiography one month later

sciousness and ischemic paresis occur in $40 \%$ of patients with proximal aortic dissection, but in our case it overlapped with arthritis and herniated disc in lumbosacral spine. $^{4}$

Aortic dissection is a rare cause of chest pain. Incidence in general population is $2.6-3.5$ per 100,000 persons. ${ }^{5}$ According to previously reported study, $22 \%$ of patients with acute aortic dissection die before reaching the hospital and $30 \%$ die during hospital admission. Increasing in incidence is more pronounced in men (52\%) compared with women $(28 \%)$ in the last 30 years. ${ }^{6}$ Hospital mortality is $25,1 \%$ according to International Registry of Aortic dissection Investigator reports in operated patients with acute type $A$ aortic dissection. ${ }^{7}$ The 30 -day mortality is lower in operated compared with non-operated patients, irrespective of age, sex and diagnosis, and is decreased from $25 \%$ to $13 \%$ in last 30 years. ${ }^{6}$

Any delay in diagnosis of acute aortic dissection increases mortality, but sometimes clinical presentation can be atypical and various, regarding of localization of dissection, complications and concomitant comorbidities. According to patient anamnesis, he had all symptoms earlier, except mild chest pain 7 days before admission during physical work, at the time when all other symptoms started. Our investigation was directed to chest pain. Differential diagnosis of chest pain includes acute coronary syndrome, chest wall pain, gastroesophageal reflux disease, panic disorder/anxiety state, pericarditis, pneumonia, heart failure, pulmonary embolism, aortic dissection. ${ }^{8}$ Patient had symmetrical, thready pulses of radial and femoral arteries, no difference in the blood pressure between the arms, and arterial hypotension could explain such findings. ECG was without changes, but there are no specific changes indicating acute aortic dissection. $31 \%$ patients with acute aortic dissection have normal ECG. ${ }^{5} 0.1-0.2 \%$ of this patients could have ST elevations. ${ }^{9}$ We performed laboratory analyses for the most common etiology of chest pain, acute coronary syndrome, but cardiospecific enzymes were negative. In some patients with acute aortic dissection troponin levels can be high and this confusion could result in a catastrophe..$^{10} \mathrm{D}$ dimer may be used as an exclusive method to role out pulmonary thromboembolism and aortic dissection, and we performed this analysis, but after negative cardiospecific enzymes ${ }^{(11)}$. Hemoglobin

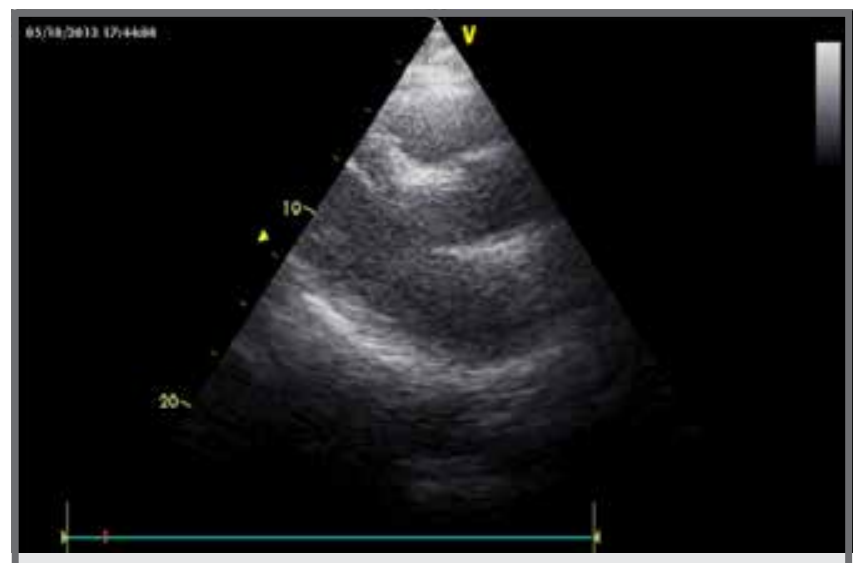

Figure 5. Echocardiography two months later

and hematocrit were low and platelet were high because of blood loss, high urea nitrogen and creatinine indicate aortic dissection and renal artery involvement.

After performed chest radiography and laboratory analysis, evaluation was oriented to possible acute aortic dissection. Further diagnostic procedures helped us to find out right diagnosis. Echocardiography showed acute aortic dissection, with pericardial hematoma, indicating that the presence of aortic dissection was earlier than admission day, probably 7 days earlier, when pain started. Echocardiography is initial modality in the emergency, and can be very useful for evaluation of ascending aorta, pericardial effusion and left ventricular function, ${ }^{12}$ and on our case this was diagnostic method of verification for aortic dissection. However, negative echocardiography does not rule out aortic dissection and other imaging technique must be considered. ${ }^{10} \mathrm{MDCT}$ has high sensitivity and specificity for its evaluation, and is therefore the most often used modality. ${ }^{13,14}$

\section{Conclusions and implications for clinical practice}

Clinicians must be aware of aortic dissection, because of its multiple clinical presentations, not only imitating, but overlapping with other diseases.

\section{References}

1. Nieman K, Hoffman U. Cardiac computed tomography in patients with chest pain. Eur Heart J. 2015 Apr 14:36(15):906-914.

2. Leite L, Baptista R, Costa JN, et al. Chest pain in the emergency department : risk stratification with Manchester triage system and HEART score. BMC Cardiovasc Disord. 2015;15:48

3. Pitts SR, Niska RW, Xu J, Burt CW. National Hospital Ambulatory Medical Care Survey: 2006 emergency department summary. Natl Heart Stat Report. 2008;7:1-3

4. Haris KM, Straus CE, Eagle KA et al. Correlates of delayed recognition and treatment of acute type A aortic dissection: the International Registry of Acute Aortic Dissection (IRAD). Circulation. 2011;124:1911-1918

5. Kim HJ, Lee K, Cho B. A case of acute aortic dissection presenting with chest pain relived by sublingual nitroglycerin. Korean J Farm Med 2013 Nov; 34(6) :429-433

6. Olsson C, Thelin S, Stahle E, Ekborn A, Granath F. Thoracic aortic aneurism and dissection: increasing prevalence and improved outcomes reported in a nationwide population-based study of more than 14,000 cases from 1987 to 2002. Circulation, 2006;114:2611-2618 
7. Trimarchi S, Nienaber CA, Rampoldi V, et al. Contemporary results of surgery in acute type aortic dissection: The International Registry of Acute Aortic dissection experience. J Thorac Cardiovasc Surg. 2005, 129:112-122

8. McConaghy J, Oza Rupal. Outpatient diagnosis of acute chest pain in adult. Am Fam Physicians 2013 Feb;1:87(3):177-182

9. Leitman M, Suzuki K, Patton B et al. Early recognition of acute thoracic dissection and aneurysm. World J Emerg Surg. 2013;8:47

10. Lentini S, Perrotta S. Aortic dissection with concomitant acute myocardial infarction: from diagnosis to management. J Emerg Trauma Shock. 2011;8(2):273-278. Doi:10.4103/0974-2700.82221

11. Hugli OW. Letter by Hugli regarding artile, Diagnosis ofacute aortic dissection by D dimer: International Registry of Acute Aortic
Dissection Substudy on Biomarkers (IRAD-Bio) experience. Circulation. 2010;121:e23

12. Evangelista A, Flachskampf F, Erbel RA ET AL. Echocardiography in aortic diseases: EAE recommendations for clinical practice. Eur J of Echocardiography. 2010;11:645-658 doi:10.1093/ejechocard/jeq056

13. Hallinan J, and Anil G. Multi- decetor computed tomography in the diagnosis and management of acute aortic syndrome. World J Radiol. 2014 Jun 28;6(6): 355-365

14. Abbas A, Brown W, Shambrook JS et al. The role of multidetector-row $\mathrm{CT}$ in the diagnosis, classifiication and management of acute aortic syndrome. Br J Radiol October 2014; 87(1042):20140354

\section{Sažetak}

\section{Preklapanje akutne disekcije aorte sa uklještenjem diska torakalne i lumbosakralne kičme}

Rada Vucic ${ }^{1,2}$, Stefan Simovic ${ }^{2}$, Mladen Kocica ${ }^{3}$, Vladimir Miloradovic ${ }^{1,2}$, Ivan Simic ${ }^{1,2}$, Olivera Andrejic ${ }^{4}$

${ }^{1}$ Odsek za Internu Medicinu, Medicinski fakultet Univerziteta u Kragujevcu, ${ }^{2}$ Klinika za kardiologiju, Klinički centar u Kragujevcu, Srbija,

${ }^{3}$ Klinika za kardiohirurgiju, Klinički centar Srbije, Srbija, ${ }^{4}$ Klinika za plućne bolesti, Klinički centar u Kragujevcu, Srbija

U prikazanom radu prikazan je pacijent sa bolom u grudima kao i torakalnoj i grudnoj kičmi za koji se sumnjalo se da je posledica ranije dijagnostikovanog uklještenja diska u torakalnoj i lumbosakralnoj kičmi, a maskirao je kliničku sliku aortne disekcije. Bol je trajao više dana, a pacijent se žalio i na vrtoglavice. Na dan prijema, pacijent je bio bez svesti 1 minut. Prvo, posumnjalo se na egzacerbaciju artritisa u torakalnoj i lumbalnoj kičmi, kao i mogući akutni koronarni sindrom. Uklještenje diska lumbosakralne kičme je potvrđeno, a akutni koronarni sindrom je isključen, dok je dalja dijagnostika potvrdila i dijagnozu aortne disekcije tip 1 po De Backey-u sa hematoperikardom koji je lečen hirurški.

Klučne reči: bol u grudima, uklještenje diska, disekcija aorte 